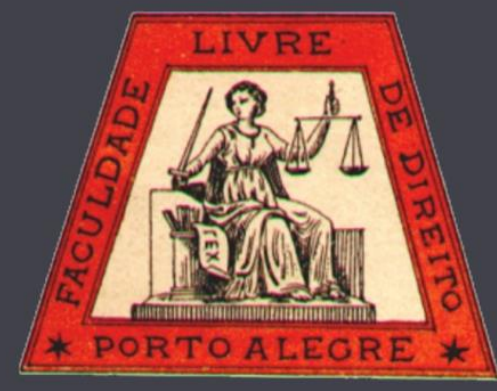

\title{
O Recurso Extraordinário 795.567/PR: análise dos fundamentos do Acórdão em face da natureza jurídica da Transação Penal
}

The Extraordinary Appeal 795,567/PR: analysis of the grounds of judgment from the perspective of the Criminal Consent Decree legal nature



\section{Everton Luis Comoreto \\ Universidade Feevale}

Karin Milene Bender

Fundação Superior do Ministério Público

Paulo Eduardo de Almeida Vieira

Universidade Feevale 


\title{
O Recurso Extraordinário 795.567/PR: análise dos fundamentos do Acórdão em face da natureza jurídica da Transação Penal
}

\author{
The Extraordinary Appeal 795,567/PR: analysis of the grounds of judgment from the perspective of \\ the Criminal Consent Decree legal nature
}

Everton Luis Comoreto*

Karin Milene Bender**

Paulo Eduardo de Almeida Vieira***

\begin{abstract}
REFERÊNCIA
COMORETO, Everton Luis; BENDER, Karin Milene; VIEIRA, Paulo Eduardo de Almeida. O Recurso Extraordinário n. 795.567/PR, análise dos fundamentos do acórdão em face da natureza jurídica da Transação Penal. Revista da Faculdade de Direito da UFRGS, Porto Alegre, n. 35, p. 287-307, dez. 2016.
\end{abstract}

\section{RESUMO}

O instituto da Transação Penal foi analisado sob o ponto de vista de sua natureza jurídica e os efeitos produzidos. Além disso foram analisados brevemente alguns conceitos básicos acerca a definição e origem do instituto da Transação. Por fim, analisou-se de maneira também breve algumas teorias acerca da Jurisdição, em especial a voluntária, a fim de melhor conceituar a transação, em sentido amplo, como método autocompositivo de solução de litígios. Ainda, analisou-se as teorias acerca da ação penal e sentença condenatória para uma melhor percepção das suas diferenças para com o instituto da transação. Como finalização, utilizou-se os fundamentos expostos no Acórdão resultante do Recurso Extraordinário n. 795.567/PR, e que versou acerca da questão trazida inicialmente, isto é, a possibilidade ou não de se extrair os efeitos extrapenais da sentença homologatória da Transação Penal, confrontando-os com toda a teoria exposta, prevendo a possibilidade da sua utilização como precedente em julgamentos futuros referentes ao tema.

\section{PALAVRAS-CHAVE}

Transação Penal. Autocomposição. Direito Processual Penal.

\section{ABSTRACT}

The institute of Criminal Consent Decree (Transação Penal) was analyzed from the point of view of its legal nature and the effects produced. In addition were briefly analyzed some basic concepts on the definition and origin of this institute. Finally, some theories on Jurisdiction were also briefly analyzed, especially the non-contentious one, in order to better conceptualize the criminal consent decree, in a broad sense, as an alternative dispute resolution method. It was also briefly examined some theories about criminal prosecution and enforceable judgment for a better perception of their differences to the criminal consent decree. At last, the expressed grounds brought in the Extraordinary Appeal 795,567/PR judgment, which dealt with the question initially raised, namely, the possibility to apply the non-criminal effects of a criminal sentence to a criminal consent decree ratification, were confronted with all the theory exposed, facing the possibility of its use as a precedent in future trials concerning the theme.

\section{KEYWORDS}

Criminal Consent Decree. Alternative Dispute Resolution. Criminal Procedure.

\footnotetext{
* Mestrando em Qualidade Ambiental pela Universidade Feevale, Rio Grande do Sul pela. Bacharel em Direito pela Universidade Feevale, Rio Grande do Sul, 2015.

** Mestre em Geologia pela Universidade do Rio dos Sinos - UNISINOS, Rio Grande do Sul, 2003. Discente de Especialização em Direito Público na Fundação Superior do Ministério Público, Rio Grande do Sul.

*** Professor na Universidade Feevale, Rio Grande do Sul. Doutorando em Direito Público pela Universidade do Vale do Rio dos Sinos - UNISINOS, Rio Grande do Sul. Mestre em Direito pela Universidade do Vale do Rio dos Sinos UNISINOS, Rio Grande do Sul, 2004.
} 


\section{SUMÁRIO}

Introdução. 1. Conceitos e Origens da Transação Penal. 1.1 Natureza Jurídica. 1.2 Transação e Ação Penal. 2. Resumo do Caso e Análise dos Fundamentos do Acórdão. 2.1 Fundamentos do Acórdão. 2.1.1 Quanto à natureza da transação e da sentença que a homologa. 2.1.2 Quanto ao efeitos extrapenais genéricos. Conclusão. Referências.

\section{INTRODUÇÃO}

A sentença que homologa o acordo de Transação Penal, prevista no artigo 76 da Lei n. 9.099/1.995, tem natureza controversa, tanto considerada declaratória, como condenatória propriamente dita. A natureza desta sentença foi discutida pelo Supremo Tribunal Federal, no Recurso Extraordinário n. 795.567/PR (BRASIL, Supremo Tribunal Federal, 2015), julgado recentemente, que analisou a possibilidade ou não, da aplicação do artigo 91, II, do Código Penal, referente aos efeitos extrapenais genéricos da condenação, isto é, o confisco dos instrumentos e bens oriundos do crime, à sentença proferida em sede de Transação Penal. Os efeitos extrapenais genéricos, seriam aplicados ou não a Transação Penal dependendo do entendimento firmado acerca a natureza da sentença que a homologa.

O Recurso Extraordinário n. 795.567/PR, foi levado a julgamento pelo Pleno do Supremo Tribunal Federal no dia 28 de Maio de 2.015, tendo o Tribunal, por unanimidade, e nos termos e fundamentos do voto do Relator, dado provimento ao recurso, entendendo ser a Transação Penal um acordo entre as partes, e a sua sentença meramente homologatória, portanto não cabíveis os efeitos extrapenais genéricos previstos no artigo 91 do Código Penal. Entretanto, o voto do Ministro Luis Fux deu provimento ao recurso, por fundamentos diversos, e firmou a tese de que a sentença que homologa a Transação Penal é condenatória, portanto, possível a aplicação do confisco à Transação Penal.

Assim, tendo em vista os dois votos discordantes que finalizaram o recurso extraordinário n. 795.567/PR, serão analisados no presente artigo os fundamentos pelos quais foram firmadas as teses propostas, tendo em vista o seu uso como precedente a orientar decisões futuras sobre o instituto da Transação Penal e a sanção do confisco. Num primeiro momento, serão apresentados alguns conceitos básicos acerca o instituto da Transação Penal, uma breve revisão da discussão acerca sua natureza jurídica, além de um breve resumo do caso, para a seguir, a análise dos principais fundamentos utilizados no Acórdão e sua pertinência com o embasamento teórico apresentado. Parte do embasamento teórico será apresentado juntamente e em confronto com os argumentos que lastrearam o Acórdão.

\section{CONCEITOS E ORIGENS DA TRANSAÇÃO PENAL}

A Transação Penal é conceituada de maneira diversa, embora exista um ponto de convergência entre diferentes conceitos, trata-se de um acordo, relativo à pena, entre as partes. $\mathrm{O}$ instituto brasileiro da Transação Penal baseia-se no sistema de Pleas norte americano, mais especificamente o Nolo Contendere Plea, e também no Patteggiamento, ou requerimento de pena antecipada pelas partes, do ordenamento jurídico italiano.

É definida juridicamente como o ato que dirime obrigações litigiosas ou duvidosas mediante concessões recíprocas das partes, ou seja, é uma composição. Possui sentido de um pacto, ajuste ou convenção onde as pessoas envolvidas promovem uma negociação, ou ainda, realizam um contrato (ZANATTA, 2001, p. 43). José Carlos Barbosa Moreira (2000, p. 
131) conceitua a Transação Penal como o acordo feito entre as partes, isto é, entre o Ministério Público e o acusado, acerca a aplicação da pena, ou seja, o acordo incide diretamente sobre a pena, e pode ser realizado somente mediante certas condições estipuladas em lei. A transação, além de concessões sobre a pena, também exclui a possibilidade da vítima utilizar a sentença como título executivo a fim de ter ressarcidos os danos causados pelo crime.

A Transação Penal também é definida como uma técnica de defesa semelhante ao instituto do Nolo Contendere, onde o acusado não admite a sua culpa nem a sua inocência, e tampouco contesta a imputação. Seria uma opção pela via do consenso ao invés do litígio. A Lei n. 9099/1995 favorece a conciliação, não implicando que o instituto da transação tenha aberto espaço para a barganha penal, isto porque não se aproxima do Plea Bargaining, típico do sistema processual penal norte americano. Enfatiza-se a similaridade entre a Transação Penal com a conformidade penal (MOLINA; GOMES, 2012, p. 491) onde se encerra ou suspende o processo imediatamente, com a aceitação da imposição de uma pena (GRINOVER et al., 1997, p. 33; 36).

\subsection{Natureza Jurídica}

A natureza jurídica da proposta de Transação Penal oferecida pelo Ministério Público e da sentença que homologa esta proposta, após a aceitação da mesma pelo autor do fato, ambas previstas no art. 76 da Lei n. 9099/1995, é muito discutida, e recebe as mais diversas definições, que variam de um acordo civil, firmado entre as partes e homologado pelo Juiz, resultante num título executivo judicial cujo objeto seria uma obrigação de pagar, fazer ou não fazer (SANTORO FILHO, 1996, p. 9-11), até uma espécie de ação penal, porém com menos formalidades, resultando, portanto, em uma sentença penal condenatória (KARAM, 2012, p. 1153).

Para Grinover et al. (1997, p. 144) a sentença que homologa o acordo da Transação Penal não pode ser considerada absolutória, já que resulta na aplicação de uma sanção penal. Também não é sentença condenatória, uma vez que não traz consigo um juízo de culpabilidade, ilicitude e a análise de conteúdo probatório, e, portanto, não traz reflexos na esfera criminal, a não ser o seu registro para a finalidade de impedir novo benefício no prazo de cinco anos. Trata-se de uma sentença homologatória, capaz de fazer coisa julgada material, além de constituir título executivo judicial. Também, por não ter natureza condenatória, a referida sentença não traz as demais consequências penais possíveis caso realmente tratasse de uma sentença condenatória. Da mesma forma, Fernando da Costa Tourinho Filho (2000, p. 92; 110 ) entende que a decisão trazida pelo $\S 4^{\circ}$ da Lei n. 9099/1995 é mera sentença de homologação do acordo de Transação Penal, não sendo condenatória já que não possui os efeitos das sentenças penais condenatórias trazidos nos artigos 91, I do CP e 63 do CPP, devendo apenas ser registrada para que o autor do fato não seja beneficiado novamente no prazo de cinco anos.

Humberto Dalla Bernardina de Pinho (1998, p. 35) traz posição contrária, onde a referida proposta deve ser considerada como uma peça primordial da ação penal condenatória, e que pode ser aplicada somente às infrações penais de menor potencial ofensivo, dentro do chamado "Espaço do Consenso", por isso de caráter especial. Assim considerada, a proposta da transação não fere os princípios Nulla Poena Sine Judicio e nem a Obrigatoriedade da Ação Penal, e a sentença a ser proferida após a aceitação pelas partes, é não somente homologatória mas também condenatória.

Ainda com o mesmo posicionamento, Afrânio Silva Jardim (1996, p. 24) entende que 
ao propor a transação, o Ministério Público estaria a exercer a ação penal, mesmo que informal e oralmente, esta traria uma imputação e pediria a aplicação da pena ao réu, mesmo que dependendo da aceitação do autor do fato. Desta maneira, continuariam vigorando os princípios da Obrigatoriedade da Ação Penal e Nulla Poena Sine Judicio, e não a Discricionariedade Regulada (GRINOVER et al. 1997, p. 144; TOURINHO FILHO, 2000, p. 92; 110). Ainda, quanto a discricionariedade, o mesmo autor (JARDIM, 1996, p. 24) admite que somente é dado ao Ministério Público a opção de escolher qual tipo de ação penal irá utilizar, a denúncia oral ou a proposta de transação, sendo ainda obrigatória a ação penal.

No entendimento de Afrânio Silva Jardim acima citado, e com o qual se coaduna Humberto Dalla Bernardina de Pinho (1998, p. 39) ao compreender o aspecto processual sob a perspectiva da proposta de transação constituir uma ação penal especial, própria das infrações de menor potencial ofensivo, não há violação aos princípios processuais penais referidos, visto que, existe ação penal, jurisdição e processo, ou seja, tem-se o devido processo legal. Visto sob esse prisma a sentença que homologa o acordo da Transação Penal seria também condenatória.

Júlio Fabbrini Mirabete (2000, p. 140-143) define a transação, como um acordo para a aplicação imediata da pena de multa ou restritiva de direitos, que não implica no reconhecimento de culpabilidade pelo autor do fato, mediante a sua aceitação da proposta feita pelo Ministério Público. A transação seria então, uma medida de caráter penal e que vem a favorecer o autor do fato, devendo ser considerada como uma técnica de defesa. A sentença proferida, neste caso, é de natureza condenatória, mas dentro do "Espaço do Consenso", tem efeitos processuais e materiais pois faz coisa julgada material e formal, pondo fim ao processo e impedindo a instauração da ação penal. Porém, à essa sentença não se aplicariam os demais efeitos penais, a não ser a imposição da pena feita na proposta e aceita, como por exemplo, o confisco trazido pelo art. 91, II, a do CP, visto tratar-se de uma sentença condenatória imprópria.

Ao tratar do assunto Pedro Henrique Demercian e Jorge Assaf Maluly (1996, p. 6263) apresentam o entendimento de que as medidas restritivas de direitos ou a multa, cumuladas com a proposta de transação, não podem ser consideradas como sanções de natureza penal em sentido estrito. Essas sanções são denominadas, pelos autores, como sanções especiais, pois não trariam o reconhecimento da culpabilidade do autor do fato e nem possuiriam o sentido de reprovabilidade ético-jurídica, como as sanções penais regulares. Muito embora recebam a denominação de penas restritivas de direitos e multa, não geram reincidência, não constam das certidões de antecedentes criminais e não surtem efeitos na esfera cível para reparação de danos.

A proposta tem por finalidade somente a exclusão do processo penal, e dos efeitos que dele decorrem. A homologação do acordo pelo Juiz é uma consequência da aceitação da proposta pelo autor do fato, e a sentença proferida, não faria coisa julgada material, somente formal (DEMERCIAN; MALULY, 1996, p. 65-66). Apesar desse entendimento, os autores concordam que, caso a medida restritiva de direitos e a multa, cumuladas com a proposta de transação forem consideradas como sanções penais propriamente ditas, haveria de se buscar uma interpretação, que equiparasse a referida proposta à uma denúncia, para se assegurar o resguardo do devido processo penal (DEMERCIAN; MALULY, 1996, p. 62).

Marcus Alan de Melo Gomes (2003, p. 8485 ; 97) rebate este entendimento, ao afirmar não ser possível a atribuição à aplicação consentida de uma pena a finalidade de excluir ou impedir o processo. As sanções previstas pela Lei n. 
9099/1995, segundo o seu entendimento, julgada.

possuem as características de uma sanção penal, decorrem de um processo, instaurado em consequência da prática de um ilícito penal, possuindo caráter aflitivo e retributivo. Atribui ainda à Transação Penal, natureza híbrida, já que satisfaz a pretensão punitiva do Estado e protege o direito de liberdade do autor do fato, uma vez que a sentença que homologa o acordo, impede a aplicação de penas restritivas de liberdade (estes seriam os efeitos materiais), além disso, ainda põe fim ao processo surtindo os efeitos formais.

Com um entendimento também contrário, Lycurgo de Castro Santos (1996, p. 130) faz uma crítica ao entendimento daqueles autores, quando definem que as penas aplicadas na Transação Penal não são penas no sentido tradicional, e não carregam um juízo de culpabilidade. $\mathrm{O}$ autor entende que a culpa é pressuposto da ingerência penal no âmbito individual, e que não pode existir uma pena desprovida de um juízo positivo de culpabilidade, sob pena de se ferir o princípio da dignidade humana, que é ao fim, o fundamento de um Estado Democrático de Direito. $O$ autor ainda afirma ser a pena ilegítima, caso não exista um processo legal, assim é forçoso entender a Transação Penal como o devido processo legal, para as infrações de menor potencial ofensivo. Cabe ao autor do fato, no momento que a proposta lhe é oferecida, optar pelo procedimento que lhe pareça mais vantajoso. A pena deva ser aplicada ao autor do fato, e em sua razão, já que se exige que se faça a imputação objetiva do fato ao agente do delito, e em um segundo momento, a imputação subjetiva, que é a culpabilidade pelo fato. Assim, finaliza o autor, não se pode fugir da natureza jurídico-penal das sanções previstas pela Lei $n$. 9.099/1.995, que são aplicadas em razão da Transação Penal. Finalizando, entende a proposta de transação como o devido processo legal, estabelecido pela referida lei, e que a sua sentença tem natureza condenatória e faz coisa
Maria Lúcia Karam (2012, p. 1153) entende ser a sentença que homologa a proposta de natureza condenatória, equiparada à uma sentença de mérito, com as características e efeitos próprios das sentenças penais condenatórias típicas, sendo apta a fazer coisa julgada material e impedindo que a demanda seja novamente levada a Juízo. A única diferença encontrada na sentença homologatória da transação, seria que esta deve ser entendida como uma chancela do Juiz ao acordo aceito pelas partes, apto a resolver o conflito, ou seja, esta resolução não seria obtida através de um julgamento de mérito tradicional, mesmo assim produz todos os efeitos inerentes às sentenças de mérito.

Para Tourinho Neto e Figueira Júnior (2011, p. 610-611; 644), não há como a sentença não ser condenatória, já que o texto da Lei n. 9099/1995 afirma que o Juiz, ao homologar o acordo, aplicará a pena, e esta pena tem as características de uma sanção penal ordinária. Então, questionam, se aplicar esta pena não seria o equivalente a condenar. Portanto, para os autores, trata-se de sentença penal condenatória do tipo sumário, de onde deriva um título judicial executivo. Ainda entendem que, o único efeito penal oriundo dessa sentença, será o seu registro, para impedir que o autor do fato seja novamente beneficiado no prazo de cinco anos.

Quanto à assunção de culpa pelo autor do fato, Tourinho Neto e Figueira Júnior (2011, p. 611) entendem existir o devido processo legal sob a forma da transação, e a posterior aplicação de uma pena mediante homologação do acordo em uma sentença condenatória, embora, mesmo aceitando o acordo e a imposição da sanção, não significa que o autor do fato deva ser considerado culpado. Este somente não contestou o que lhe foi imputado, não fez uma confissão de culpa. Ao aceitar a proposta, escolheu por não responder a um processo, e não 
se submeter a instrução criminal, aos debates orais, preferiu a tranquilidade. Assim, segundo os autores, também não se fere o princípio da presunção da inocência.

Geraldo Prado (2003, p. 216-217) afirma que o procedimento previsto no art. 76 da Lei $n$. 9.099/1.995 somente pode ser aceito se visto sob a ótica de ser tão somente uma faculdade da defesa, de abrir mão do devido processo legal. Caso fosse possível impor pena de prisão no acordo de Transação Penal, esta estaria em desacordo com a Constituição Federal. Ao finalizar o raciocínio, o autor afirma em suas conclusões que não há o devido processo legal na Transação Penal brasileira, tratando-se de técnica de defesa.

Ao tratar da natureza jurídica da Transação Penal, Luís Paulo Sirvinskas (2000, p. 460-462) lhe atribui natureza cível, afirmando tratar-se de um negócio jurídico extrapatrimonial. Não se trata de transação, pois esta só é possível quando se tratar de direitos patrimoniais de caráter privado, já o negócio jurídico, admite não só questões patrimoniais, mas também, matéria extrapatrimonial. Desta maneira, seria possível ao indivíduo que cometeu a infração penal de menor potencial ofensivo, negociar a sua liberdade, mediante a aceitação de pena não privativa de liberdade, em um acordo firmado livremente com o Promotor de Justiça. Assim, não existiria na transação um processo penal propriamente dito, nem as garantias do devido processo legal e demais garantias previstas na Constituição Federal, consequentemente não há pena a ser aplicada, e por este motivo, entende que se trata de uma sanção especial e não uma sanção penal. Trata-se de medida judicial sem consequência penal.

\subsection{Transação e Ação Penal}

No ordenamento jurídico brasileiro, mais precisamente no Código Civil de 2002, pode-se dizer que a transação é o ato por meio do qual os interessados previnem ou terminam litígios mediante concessões mútuas. Isto significa que, do ponto de vista processual, as partes dispensam a intervenção direta do órgão jurisdicional para resolver o litígio no qual estão envolvidas, que no caso levaria a uma heterocomposição. As práticas autocompositivas têm sido incentivadas nas legislações modernas, não só no âmbito do direito processual civil, onde são mais tradicionalmente aceitas, isto por se cuidarem de direitos em geral disponíveis, mas também no contexto do processo penal (GROSSI, 2015, p. 133-171).

A autocomposição, enquanto poder reconhecido à vontade dos interessados para tutela de seus interesses, manifesta-se seja por meio de ato simples ou de um ato complexo. Nessa distinção, tem-se apenas a suficiência da vontade de uma das partes ou a necessidade do consentimento de ambas para estabelecer a composição do litígio. A primeira corresponderia à renúncia e ao reconhecimento, e a segunda, à transação. Quando celebrada no curso do processo, a transação reúne aspectos tanto da renúncia a direito quanto do reconhecimento do pedido. Isso porque, de um lado, o réu se submete em parte à pretensão do autor e, de outro, o autor resigna-se a obter resultado menos vantajoso que o desejado (WAMBIER, 2004, p. 240).

A transação, então, não é mais do que acordo de vontades, ou um negócio complexo bilateral, onde os acordantes dispõem a sua própria situação jurídica (WAMBIER, 2004, p. 240). Significa que, a composição ou a prevenção do litígio não são, unicamente, a causa da transação. No entanto, para que esse acordo possa ser caracterizado como transação, é preciso que a composição ou a prevenção do litígio ocorra com sacrifício recíproco, o que explica sua natureza bilateral (CASTILLO, 1992, p. 68). Dentro desse raciocínio, o ato 
judicial que homologa a transação somente pode ser considerado sentença formalmente. Como não há qualquer apreciação sobre o mérito da causa, o que o órgão julgador realiza quando lhe submetem instrumento de transação para ser homologado, é um mero juízo de delibação, o órgão julgador apenas procede ao exame externo dos atos dispositivos das partes (WAMBIER, 2004 , p. 240). Isso não significa dizer que, e em especial em matéria penal, não exista uma resolução judicial, mas somente que a homologação não é verdadeira resolução jurisdicional do conflito objeto de um processo. A homologação tem a forma de uma sentença, mas não forma sentença (CASTILLO, 1992, p. 82).

O Ministério Público, na Transação Penal, oferece ao autor do fato a aplicação de uma pena de multa, pecuniária, ou mesmo a aplicação de pena de prestação de serviços à comunidade, o que consiste em uma restrição da liberdade, correspondendo à pena restritiva de direitos, prevista no Código Penal. No acordo, o Ministério Público desiste da apresentação da ação penal e, em contrapartida, o autor do fato desiste de se ver absolvido, não tem o ônus de ser réu em processo criminal ordinário, mas abre mão de participar da produção de provas e de provar sua inocência (REALE JÚNIOR, 2012, p. 321-345). A Transação Penal brasileira não gera reconhecimento de culpa, não se é punido, porque não há condenação resultante da averiguação da culpabilidade. $\mathrm{O}$ acordo penal diz respeito, apenas, aos delitos de culpabilidade reduzida e não a julgamentos com o reconhecimento da culpa, que impõem uma pena restritiva de liberdade. Ou seja, inexiste formação de sentença condenatória e a transação não implica em quaisquer consequências jurídicas que não a vedação ao oferecimento de nova proposta de transação para o mesmo delito em um período de cinco anos (GROSSI, 2015, p. 133-171).
Na Transação Penal, diferentemente da transação prevista pelo Código Civil, o Supremo Tribunal Federal, fixou o entendimento, já pacificado em vários julgados (BRASIL, Supremo Tribunal Federal, 2005, HC 86.694/SP; BRASIL, Supremo Tribunal Federal, 2011, Re 619.224/MG), de que, diante do descumprimento do acordo homologado, retorna-se ao status quo ante, isto é, surge ao Ministério Público a autorização para a persecução penal. Deste entendimento chegou-se a inteligência da Súmula Vinculante de número 35, editada no ano de 2014. Isto significa dizer que, o acordo homologado não forma título executivo judicial sujeito à execução forçada (WAMBIER, 2004, p. 240-241; BRASIL, Supremo Tribunal Federal, 2006, HC 88.785/SP) e a extinção da punibilidade se dá somente após o cumprimento do acordo, isto é, após o pagamento de multa e/ou o cumprimento da pena restritiva de direitos.

O Estado exercita a tutela jurisdicional penal, isto é, a tutela dos bens juridicamente relevantes, por meio da ação penal, e nos casos onde existe a pretensão punitiva como seu objeto, sua forma é a ação penal condenatória. Como conceito de ação penal, tem-se então, um direito subjetivo público de invocar a prestação jurisdicional do Estado, em face a uma determinada pretensão, lastreada em norma penal ou processual penal. Isto porque nem sempre a pretensão é punitiva, como nos casos de Habeas Corpus e ação de Revisão Criminal, onde a pretensão é de liberdade (JARDIM, 2001, p. 3334).

O conteúdo do processo de condenação é então a declaração do ato ilícito e também a declaração da responsabilidade por ele. Caso o ato ilícito reclamar uma sanção, que é aplicada por meio da coação, a responsabilidade por ele é que determina a sujeição do autor do fato à sanção. Assim, caso determinado ato ilícito necessite de uma sanção, seu autor é 
necessariamente responsável. No caso do processo condenatório, o acertamento do ato ilícito é o objetivo primário, porém nele não se esgota o acertamento quanto a responsabilidade, no seu conteúdo também se determina a sanção a ser aplicada. Neste aspecto, o processo condenatório é parte do processo declaratório, uma vez que o Juiz aplica, obrigatória e vinculativamente a norma jurídica. A diferença entre ambos reside no objeto do acertamento, que não é uma relação jurídica, mas sim a relação jurídica que o autor denominou de responsabilidade. No processo condenatório, o Juiz então, prepara a execução, no sentido de acertar a sanção a que o obrigado (responsável) deve ser submetido (CARNELUTTI, 2000, p. 230).

Ao discorrer acerca a eficácia declaratória contida na sentença condenatória, o chamado efeito declaratório da sentença, Ovídio da Silva Baptista (2011, p. 287) entende que esta corresponde ao juízo de subsunção praticado pelo julgador, ao considerar incidente no caso concreto a regra normativa constante da lei, e nesse sentido, semelhante ao conceito de "acertar" a norma jurídica à relação jurídica existente, isto é, dizer o que o Direito quer àquele caso concreto conforme Francesco Carnelutti (2000, p. 229). Declarar, em sentença judicial, seria então afirmar que a espécie submetida à decisão, está sujeita a determinada disciplina legal. Ao declarar procedente a ação e o demandado responsável pela prestação exigida, efeito declaratório da sentença condenatória, o Juiz, na sentença declara que determinado preceito de lei incidiu e é aplicável à espécie litigiosa. Por esse motivo, o Juiz condena o demandado a sanção, se a demanda é condenatória, ou seja, ao cumprimento da prestação declarada existente e exigível (BAPTISTA, 2011, p. 287).

Ainda, considera que que todas as sentenças, mesmo aquelas proferidas em procedimentos de jurisdição voluntária, terão eficácia declaratória, isto é, aptas a produzir efeito declaratório. Contudo em relação aos procedimentos de jurisdição voluntária, explica o autor que, por inexistir um conflito de interesses atual, a ordem jurídica não entende necessário estender a estes a indiscutibilidade inerente à coisa julgada, o que faz com que a eficácia declaratória destas sentenças se esvazie, tornando-as incapazes de produzir coisa julgada (BAPTISTA, 2011, p. 287).

Eficácia é termo para designar a qualidade do ato enquanto gerador de efeitos. Também pode-se falar em eficácia como uma aptidão potencial para produzir efeitos, ou ainda, como conjunto de efeitos já produzidos em um ato ou, embora com menos frequência, como sinônimo de efeito, e nesse caso, para designar cada um dos efeitos, tanto os potenciais como os já ocorridos, considerados individualmente. Isso faz com que se atribua ao mesmo ato jurídico uma pluralidade de eficácias (MOREIRA, 1985, p. 7). Para cada ato jurídico, são atribuídos efeitos correspondentes ao seu conteúdo, isso não excluindo também, que se atribuam efeitos iguais a atos de diferentes conteúdos, ou viceversa. Não é necessário que entre o ato jurídico e os seus efeitos, exista nexo de causalidade, uma vez que esta pode ser substituída pelo conceito de imputação, ainda assim, dependerá do conteúdo do ato os efeitos que este potencialmente produzirá ou já produziu. Isto não significa que o efeito produzido pelo ato se identifique ou se confunda com o respectivo conteúdo, ou faça parte desse conteúdo. O efeito é algo que está necessariamente, por definição, fora daquilo que o produz, quer se trate de fato natural, quer de ato jurídico (MOREIRA, 1985, p. 7). 
2 RESUMO DO CASO E ANÁLISE DOS FUNDAMENTOS DO ACÓRDÃO

Trata-se na origem, de um procedimento penal instaurado pelo $2^{\circ}$ Juizado Especial Criminal da Comarca de Londrina para apurar o cometimento de contravenção penal, tipificada no artigo 58 do Decreto-lei 3668 de 03 de Outubro de 1941, e que teve motocicleta de sua propriedade, supostamente utilizada na execução do ilícito, apreendida por ocasião da lavratura de termo circunstanciado anteriormente mencionado.

Ofertada transação, foi ela acolhida e integralmente cumprida pelo investigado, o que veio a ser reconhecido por sentença extintiva de punibilidade, onde restou decretada a perda do veículo antes apreendido, e imposta a sanção prevista no artigo 91, inciso II, alínea "a" do Código Penal, com fundamento no artigo 779 do Código de Processo Penal, combinado com o artigo 1 do Decreto-lei $n^{\circ}$ 3668/1941, a Lei das Contravenções Penais. Contra essa sentença foi interposta apelação, que restou desprovida pela Turma Recursal do Tribunal de Justiça do Estado do Paraná. Na sequência, foram opostos embargos declaratórios, também rejeitados. Assim, foi então interposto Recurso Extraordinário, que teve como fundamento a alegação que o direito de propriedade do autor do fato teria sido atingido sem a observância do devido processo legal, visto que o acórdão recorrido teria lhe infligido uma sanção penal sem que houvesse uma ação penal para apuração dos fatos narrados no termo circunstanciado, e isto atentaria contra as garantias do contraditório e da ampla defesa. Ainda sustentou que a aplicação de efeitos equivalentes aos da confissão em sede de Transação Penal afrontaria a presunção de inocência, e portanto, impossível extrair-se essa mesma consequência de um ato transacional. Inadmitido na origem, seus autos foram submetidos ao Supremo Tribunal Federal por meio de agravo de instrumento. Após a análise da existência de repercussão geral, foi provido o agravo, e na sequência, determinado sua conversão em recurso extraordinário, que foi, por fim, admitido e provido.

\subsection{Fundamentos do Acórdão}

O Recurso Extraordinário $\mathrm{n}^{\mathrm{o}} 795.567 / \mathrm{PR}$ foi levado a julgamento pelo Pleno do Supremo Tribunal Federal e após os votos dos Ministros Teori Zavascki (Relator), Roberto Barroso e Rosa Weber, que lhe deram provimento, pediu vista aos autos o Ministro Luiz Fux. Por fim, o Tribunal, por unanimidade, e nos termos e fundamentos do voto do Relator, deu provimento ao recurso extraordinário, entendendo ser a transação um acordo entre as partes, e sua sentença homologatória, portanto não cabíveis os efeitos extrapenais genéricos. A tese fixada na decisão do Recurso Extraordinário teve o seguinte teor:

As consequências jurídicas extra penais, previstas
no art. 91 do Código Penal, são decorrentes de
sentença penal condenatória. Tal não ocorre,
portanto, quando há Transação Penal, cuja sentença
tem natureza meramente homologatória, sem
qualquer juízo sobre a responsabilidade criminal do
aceitante. As consequências geradas pela Transação
Penal são essencialmente aquelas estipuladas por
modo consensual no respectivo instrumento de
acordo (BRASIL, Re. $795.567 / P R, 2015)$.

No seu voto o Ministro Luis Fux deu provimento ao recurso, devido a impossibilidade, no caso concreto, do confisco de bem pertencente ao autor do fato cuja posse não seja ilícita, sob pena de violação do direito constitucional à propriedade. Entretanto, entendendo a sentença que homologa a Transação Penal como condenatória e, portanto, possível a aplicação do confisco à Transação Penal, firmou a sua tese da seguinte maneira:

É constitucional a aplicação dos efeitos 
condenação estabelecidos no art. 91, II, do Código Penal, às sentenças homologatórias de Transação Penal, tendo em vista sua natureza condenatória, ausente violação aos princípios do devido processo legal, da ampla defesa, do contraditório e da presunção de inocência, desde que observado o disposto na Lei 9.099/95 e, subsidiariamente, no Código Penal e no Código de Processo Penal.

A partir das duas teses firmadas, serão analisados na sequencia os principais fundamentos pelos quais os dois votos, com teses distintas, e que deram provimento ao recurso, foram desenvolvidos. A análise será feita confrontando a fundamentação dos votos com o embasamento teórico exposto nos capítulos e itens anteriores, com o objetivo de verificar a sua aderência aos diferentes posicionamentos apresentados. O texto a seguir será dividido em itens, confrontando os argumentos utilizados nos votos com a teoria agrupados em razão do assunto principal tratado. Essa análise servirá de base e será finalizada no item Considerações Finais.

2.1.1 Quanto à natureza da transação e da sentença que a homologa

A Lei $n^{\circ}$ 9.099/1995 introduziu no sistema penal brasileiro o instituto da transação, que, nos termos do seu artigo 76 e $\S \S$, permite a dispensa pelo magistrado da persecução penal nos casos de crimes de menor potencial ofensivo, desde que o suspeito da prática do delito concorde em se submeter, sem qualquer resistência, ao cumprimento de uma pena restritiva de direito ou multa que lhe tiver sido ofertada por representante do Ministério Público em audiência. Ao assim dispor, a lei relativizou, de um lado, o princípio da obrigatoriedade da instauração da persecução penal em crimes de ação penal pública de menor ofensividade, e, de outro, autorizou o investigado a dispor das garantias processuais penais que o ordenamento lhe confere. As consequências geradas pela Transação Penal da Lei 9.099/95 hão de ser essencialmente aquelas estipuladas no instrumento do acordo. Recurso Extraordinário 795.567/Paraná. Voto Relator: Ministro Teori Zavascki.

A natureza jurídica da sentença homologatória da Transação Penal pressupõe que seja considerado o principal elemento que a constitui: a aplicação de uma sanção penal ao autor do crime de menor potencial ofensivo levado à apreciação do Judiciário. Recurso Extraordinário 795.567/Paraná. Voto-vista: Ministro Luis Fux.

A dogmática processual e a exegese das normas legais sobre o thema iudicandum conduzem à conclusão de que a aplicação de uma sanção penal a ser cumprida pelo apenado atribui à sentença natureza condenatória, ainda que desprovida de alguns dos efeitos da condenação criminal tradicional, na pré-compreensão da Corte incumbida da uniformização da exegese acerca das "leis penais" em sentido lato, o Superior Tribunal de Justiça. Precedentes. Recurso Extraordinário 795.567/Paraná. Voto-vista: Ministro Luis Fux.

O Direito Penal, regido, por excelência, pelo princípio da legalidade, conduz ao entendimento de que a exclusão, pelo legislador, de alguns dos efeitos da condenação, confirma o entendimento de que a sentença homologatória possui natureza condenatória, desprovida apenas dos efeitos expressamente afastados pela Lei 9.099/95. Recurso Extraordinário 795.567/Paraná. Votovista: Ministro Luis Fux.

A transação é acordo de vontades, um negócio bilateral, onde os acordantes dispõem a sua situação jurídica. Dessa forma, além da composição ou a prevenção do litígio, a causa da transação é definir autocompositivamente a situação jurídica dos interessados sem a necessidade de se submeter a uma decisão obrigatória de um terceiro. No entanto, para que esse acordo possa ser caracterizado como transação, é preciso que a composição ou a prevenção do litígio ocorra com sacrifício recíproco, o que explica sua natureza bilateral (WAMBIER, 2004, p. 240).

No ordenamento jurídico brasileiro, de acordo com o disposto no Código Civil de 2002 pode-se dizer que a transação é o ato por meio do qual os interessados previnem ou terminam litígios mediante concessões mútuas. Isto significa que, do ponto de vista processual, as 
partes dispensam a intervenção direta do órgão jurisdicional para resolver o litígio no qual estão envolvidas, que no caso levaria a uma heterocomposição. As práticas autocompositivas têm sido incentivadas nas legislações modernas, não só no âmbito do direito processual civil, onde são mais tradicionalmente aceitas, isto por se cuidarem de direitos em geral disponíveis, mas também no contexto do processo penal (GROSSI, 2015, p. 133-171).

É vedado ao Juiz da causa qualquer verificação a respeito da conveniência ou não dos termos ajustados na transação, assim como também lhe é vedada qualquer avaliação sobre a pertinência desses ajustes em face das oportunidades de vitória que porventura estariam sendo desperdiçadas por uma das partes ao negociar. Ao Juiz cabe apenas o dever de verificar os aspectos formais do próprio ato sujeito a homologação, mas nunca apreciar a substância deste, ainda que a entenda lesiva para um dos interessados. Estando o ato formalmente perfeito e a vontade das partes manifestada de modo regular, é o que basta. Disso, decorre para o Juiz o dever de resignar-se à vontade das partes e homologar o ato de disposição do direito, ainda quando contrário à sua opinião (ARRUDA ALVIM, 2002, p. 15-44).

Poder-se-ia distinguir, então, como características dos juízos de jurisdição voluntária, a maior agilidade, menor formalismo, possível limitação de certas garantias, mas com a preservação das garantias fundamentais existentes nos processos contraditórios, maior economia processual e poderes mais extensos ao Juiz, para atuar nos casos onde inexistem controvérsias entre partes, ou então que estas não sejam especialmente relevantes, onde atuaria por imposição legal, na defesa do interesse público ou social, ou autorizando e controlando pretensões com caráter constitutivo. Seus objetivos seriam a negociação, a prevenção da jurisdição contenciosa e o caráter constitutivo de seus atos (BUJÁN, 2001, p. 89-148).

Dentro desse raciocínio, o ato judicial que homologa a transação somente pode ser considerado sentença formalmente. Como não há qualquer apreciação sobre o mérito da causa, o que o órgão julgador realiza quando lhe submetem instrumento de transação para ser homologado, é um mero juízo de delibação, o órgão julgador apenas procede ao exame externo dos atos dispositivos das partes (WAMBIER, 2004, p. 240). Isso não significa dizer que, e em especial em matéria penal, não exista uma resolução judicial, mas somente que a homologação não é verdadeira resolução jurisdicional do conflito objeto de um processo. A homologação tem a forma de uma sentença, mas não forma sentença (CASTILLO, 2000, p. 82).

$\mathrm{Na}$ teoria do fato jurídico, o negócio jurídico é uma espécie de ato jurídico lato sensu, aqueles atos humanos que têm na vontade o seu elemento nuclear e não se constituem em ilícito. Ainda, no negócio jurídico, os interessados podem dentro de certos limites, autor regrar os seus interesses, permitindo a escolha de categorias jurídicas, de acordo com as suas conveniências, possibilitando também a definição do conteúdo eficacial das relações jurídicas surgidas do acordo (MIRANDA, 1954, p. 55-57). A Transação Penal pertence ao Direito Penal, mesmo que o acordo seja feito pelo autor do fato e pelo Ministério Público para produzir efeitos processuais, mas a transação em si é figura contratual, vale dizer, pertencente ao Direito Material Penal, isto porque o acordo prevê a aplicação de pena, e a disciplina do sistema de penas é tarefa do Direito Penal (PORTO, 2012, p. 867-887).

$\mathrm{O}$ princípio que norteia os procedimentos auto compositivos, dentre eles a transação, é o da 
verdade consensual, a verdade acordada pelas partes (GRINOVER et al., 1997, p. 39). Outro aspecto importante da transação, e dos demais métodos auto compositivos, é a predominância do Princípio Dispositivo (CASTILLO, 2000, p. 81-82). Em sentido oposto vem o processo penal, onde o princípio informativo é o da verdade real (JARDIM, 1997, p. 20).

O conteúdo dos processos de condenação em geral, e especificamente o processo penal condenatório, é a declaração do ato ilícito e também a declaração da responsabilidade por ele. Caso o ato ilícito, a infração penal, reclamar uma sanção, a responsabilidade por ele é que determina a sujeição do autor do fato à sanção. Assim, caso determinado ato ilícito necessite de uma sanção, seu autor é necessariamente responsável. No caso do processo condenatório, o acertamento do ato ilícito é o objetivo primário, porém nele não se esgota o acertamento quanto a responsabilidade, no seu conteúdo também se determina a sanção a ser aplicada. Neste aspecto, o processo condenatório é parte do processo declaratório, uma vez que o Juiz aplica, obrigatória e vinculativamente a norma jurídica (CARNELUTTI, 2000, p. 223224). Assim, os efeitos das providências de condenação não se restringem somente à declaração do preceito primário, mas também consistem em possibilitar a execução forçada e submeter o condenado à força física, caso necessário, para a observação do Direito (CALAMANDREI, 1999, p. 174).

A sentença é definida como a decisão da causa de acordo com a lei e a prova dos autos, ou ainda, é a decisão proferida pelo Juiz, solucionando a causa. É terminativa quando põe fim ao processo sem julgar-lhe o mérito e, definitiva, quando conhece do mérito, pondo fim ao processo. A sentença penal, ao contrário da cível, busca a verdade real e não a formal, e devido à essa exigência, a prova de que o réu praticou uma ação típica, antijurídica e culpável, isto é punível (MACHADO, 1991, p. 271-284; TUCCI, 2012, p. 263).

A eficácia declaratória contida na sentença condenatória, isto é, o efeito declaratório da sentença, corresponde ao juízo de subsunção praticado pelo julgador, ao considerar incidente no caso concreto a regra normativa constante da lei, e nesse sentido, semelhante ao conceito de "acertar" a norma jurídica à relação jurídica existente, isto é, dizer o que o Direito quer àquele caso concreto. Declarar, em sentença judicial, seria então afirmar que a espécie submetida à decisão, está sujeita a determinada disciplina legal. Ao declarar procedente a ação e o demandado responsável pela prestação exigida, efeito declaratório da sentença condenatória, o Juiz, na sentença declara que determinado preceito de lei incidiu e é aplicável à espécie litigiosa. Por esse motivo, o Juiz condena o demandado a sanção, se a demanda é condenatória, ou seja, ao cumprimento da prestação declarada existente e exigível (CARNELUTTI, 2000, p. 229; SILVA, 2011, p. 287).

Todas as sentenças, mesmo aquelas proferidas em procedimentos de jurisdição voluntária, terão eficácia declaratória, isto é, aptas a produzir efeito declaratório. Contudo em relação aos procedimentos de jurisdição voluntária, por inexistir um conflito de interesses atual, a ordem jurídica não entende necessário estender a estes a indiscutibilidade inerente à coisa julgada, o que faz com que a eficácia declaratória destas sentenças se esvazie, tornando-as incapazes de produzir coisa julgada (SILVA, 2011, p. 287).

Para cada ato jurídico, são atribuídos efeitos correspondentes ao seu conteúdo, isso não excluindo também, que se atribuam efeitos iguais a atos de diferentes conteúdos, ou viceversa. Não é necessário que entre o ato jurídico e os seus efeitos, exista nexo de causalidade, uma vez que esta pode ser substituída pelo conceito 
de imputação, ainda assim, dependerá do conteúdo do ato os efeitos que este potencialmente produzirá ou já produziu. Isto não significa que o efeito produzido pelo ato se identifique ou se confunda com o respectivo conteúdo, ou faça parte desse conteúdo. O efeito é algo que está necessariamente, por definição, fora daquilo que o produz, quer se trate de fato natural, quer de ato jurídico (MOREIRA, 1985, p. [sp]).

\subsubsection{Quanto ao efeitos extrapenais genéricos}

A imposição da medida confiscatória sem processo revela-se antagônica não apenas à acepção formal da garantia do art. $5^{\circ}$, LIV, da CF, como também ao seu significado material, destinado a vedar as iniciativas estatais que incorram, seja pelo excesso ou pela insuficiência, em resultado arbitrário. No particular, a excessividade do decreto de confisco reside no fato de que a aceitação da transação reverteu em claro prejuízo daquele a quem deveria beneficiar (o investigado), pois produziu contra ele um efeito acessório - a perda da propriedade de uma motocicleta - que se revelou muito mais gravoso do que a própria prestação principal originalmente avençada (pagamento de 5 cestas de alimentos). Recurso Extraordinário 795.567/Paraná. Voto Relator: Ministro Teori Zavascki.

Os efeitos automáticos da condenação, previstos no art. 91, II, do Código Penal, representam mero imperativo lógico da aplicação de pena ao autor do crime de menor potencial ofensivo que ensejou a formulação da proposta de Transação Penal pelo Estado-Acusador e ao seu acolhimento pelo EstadoJuiz. Consectariamente, esse efeito impede que o réu mantenha a posse ilícita de bens ou instrumentos do delito cuja posse. Recurso Extraordinário 795.567/Paraná. Voto-vista: Ministro Luis Fux.

A potencial gratificação propiciada pelo crime é anulada quando se observa sob seu aspecto econômico, devido ao risco de sujeição às penas cominadas, em especial a privação da liberdade. Com a anulação da gratificação no cometimento da infração penal, se espera, como consequência, o seu desaparecimento. São três os fatores que poderiam explicar a continuidade do crime: (1) a percepção de um baixo risco potencial de efetiva punição, por parte do infrator; (2) um grau elevado de satisfação pessoal por parte do infrator, com a prática do crime, sendo impossível desmotivá-lo através da cominação de um mal; e (3) por fim, a apreciação do infrator relativamente à compensação trazida pelo crime é diferente daquela que o Estado supõe ao cominar as penas. A sujeição à pena não anularia o sentimento de compensação material trazida pelo crime. Nesse sentido a pena não seria mais do que o custo eventual, de um benefício econômico. A diferença com os outros dois fatores, está em que a eliminação deste benefício se encontra ao alcance do Estado (CAEIRO, 2013, p. 453-501).

Por perda, ou confisco, entendemos as medidas que instauram o domínio do Estado sobre certos bens ou valores, fazendo cessar os direitos reais e obrigacionais que sobre eles porventura incidissem, bem como outras formas de tutela jurídica dos estados de fato que os tivessem por objeto, como por exemplo a posse (CAEIRO, 2013, p. 453-501). No ordenamento brasileiro o confisco está previsto no artigo 91, II do Código Penal e se refere aos bens cujo porte, fabrico, alienação, uso ou detenção constitua fato ilícito, bem como aqueles que constituam proveito da prática delituosa ilícitos ou não.

O principal efeito da sentença condenatória é fixar a pena, como efeito secundário, tem-se o confisco, de natureza extrapenal, porém decorrente da fixação da pena. Este efeito é automático e não necessita que o Juiz o declare na sentença, além disso não possui cunho retributivo, mas orientado pela prevenção, pois inviabiliza as situações que propiciam a prática delituosa desestimulando-a (NUCCI, 2014, p. 561-565).

O confisco é considerado como uma modalidade de sanção, que parece atingir com maior eficácia o objetivo de dissuasão do agente criminoso, uma vez que traz consigo um risco com o qual o criminoso não é capaz de lidar, 
diferentemente de penas como a multa, cujo valor pode de alguma forma ser contabilizado na estratégia delitiva. É uma sanção dotada de grande capacidade intimidatória sobre o agente, ao mesmo tempo em que impede a fruição dos proveitos auferidos com o crime. Com essa sanção atende-se uma orientação de prevenção geral, reforçando a dignidade do ordenamento violado perante a coletividade. Por fim, ao fixar como limite da perda as vantagens do crime, e ainda prever o confisco dos bens ou valores equivalentes, a legislação brasileira dá um sinal do quão severa pode ser a medida (PANZERI, 2011, p. 43-79).

A perda de bens em favor do Estado pode se mostrar como instrumento adequado à contenção da criminalidade, mais adequada que a multa, por ser capaz de atuar em uma esfera patrimonial mais ampla, e também por ter seus limites de fixação de valor não são tão rígidos como os da multa (PANZERI, 2011, p. 43-79). Ainda, em razão da situação de abandono na qual se encontram os estabelecimentos prisionais brasileiros, o que impede a realização dos fins da pena, isto é, a reinserção do criminoso na sociedade e a contenção da criminalidade, parece tornar o cárcere muito mais um método que impulsiona a violência. Assim, o recrudescimento do sistema penal brasileiro mostra-se consequência lógica diante do aumento da criminalidade, devido a ineficácia desse mesmo sistema. Desta maneira, as penas alternativas e as demais medidas descarcerizantes passam a não contar com o apoio da sociedade. As medidas descarcerizadoras trazidas pela Lei n. 9099/1995, para que sejam efetivas e constituam uma resposta adequada ao delito, precisam estar aliadas a um maior controle na sua aplicação e cumprimento (AZEVEDO, 2011, p. [sp]), o que estaria em sentido oposto ao da não aplicação do confisco à Transação Penal, gerando ainda mais desconfiança por parte da população em relação às medidas descarcerizadoras.

\section{CONCLUSÃO}

No tocante a natureza da sentença que homologa a Transação Penal, não há óbice que esta seja considerada como de conteúdo condenatório, visto que a eficácia do provimento judicial depende justamente deste conteúdo, seja ele acordado pelas partes, ou acertado pelo Juiz. A sentença homologatória chancela a aplicação da pena, isto é, condena o autor do fato ao seu cumprimento, justamente por ter com ela concordado. Na transação são os interessados que determinam a sua situação jurídica e portanto, determinam o conteúdo do provimento judicial. $\mathrm{O}$ que determina a natureza da sentença é o seu conteúdo, e sendo este penal, isto é, determina a aplicação de uma pena, a eficácia da sentença homologatória de transação também poderia ser considerada condenatória.

Considerando-se a eficácia condenatória da sentença de homologação da Transação Penal, e sendo eficácia a capacidade para produzir efeitos, estes não integram o seu conteúdo, efeito é algo que está necessariamente, por definição, fora daquilo que o produz, quer se trate de fato natural, quer de ato jurídico. Limitada essa sentença por previsão legal, quanto aos efeitos penais, mantido somente a obrigação ao cumprimento da pena, os efeitos secundários e que não dependem da verificação da culpabilidade também poderiam ser mantidos.

A sentença da Transação Penal, no entanto, não se equivale a uma sentença penal condenatória, resultante do processo penal, já que esta busca, a princípio, a Verdade Real (a verdade aproximada) e não a formal ou consensuada, e devido à exigência da verdade real, a prova de que o réu praticou uma ação típica, antijurídica e culpável, isto é punível, precisa ser feita pelo Ministério Público, mesmo nos casos onde o réu é revel, ou ainda, quando 
confessa ter cometido a infração penal.

Sob essa ótica, nada impede que os efeitos extra penais genéricos sejam também atribuídos à sentença que homologa a Transação Penal. A sanção do confisco desempenha um importante papel na dissuasão do agente em cometer infrações penais, visto que impede que mantenha os benefícios e os instrumentos do crime. É portanto uma sanção com finalidade preventiva e não retributiva, compatível com os princípios que informam o modelo de justiça consensual trazida pela Lei n. 9099/1995, mais que isso, é uma questão de política criminal, permitir ou não que o acusado permaneça com as vantagens e instrumentos da infração penal.

\section{REFERÊNCIAS}

ARRUDA ALVIM. Direito Privado. v. 2. Coleção Estudos e Pereceres II. São Paulo: Revista dos Tribunais, 2002.

AZEVEDO, Rodrigo Ghiringhelli de. Descarcerização e Segurança Pública. Fórum Brasileiro de Segurança Pública. Carta Capital, [sp.], 2011. Disponível em: <http://www.cartacapital.com.br/sociedade/descarcerizacao-e-seguranca-publica>. Acesso em: 19 jun. 2016.

BRASIL. Supremo Tribunal Federal, 2001. Recurso Extraordinário 619.224/MG. Disponível em: <http://www.stf.jus.br/portal/processo/verProcessoAndamento.asp?incidente=3897611> Acesso em: 23 jun. 2016.

Supremo Tribunal Federal, 2005. Habeas Corpus 86.694/SP. Disponível em: <http://redir.stf.jus.br/paginadorpub/paginador.jsp?docTP=TP\&docID=4507299>. Acesso em: 23 jun. 2016.

Supremo Tribunal Federal, 2006. Habeas Corpus 88.785/SP. Disponível em: <http://stf.jusbrasil.com.br/jurisprudencia/760290/habeas-corpus-hc-88785-sp>. Acesso em: 15 nov. 2015.

Supremo Tribunal Federal, 2015. Recurso Extraordinário 795.567/PR. Disponível em: $<$ http://www.stf.jus.br/portal/processo/verProcessoAndamento.asp?incidente=4527270 $>$ Acesso em: 08 nov. 2015.

BUJÁN, Antonio Fernández de. Los principios informadores de la jurisdicción voluntaria: una propuesta de futuro. AFDUAM, n. 5, p. 89-148, 2001. Disponível em: <https://www.uam.es/otros/afduam/pdf/5/6900111(089-148).pdf>. Acesso em: 15 set. 2015.

CAEIRO, Pedro. Sentido e Função do Instituto da Perda de Vantagens Relacionadas com o Crime no Confronto com Outros Meios de Prevenção da Criminalidade Reditícia. Revista Brasileira de Ciências Criminais, São Paulo: Revista dos Tribunais, v. 100, p. 453-501, jan. - fev. 2013. Disponível em: <http://www.revistadostribunais.com.br/maf/app/resultList/document?\&src=rl\&srguid=i0ad8181500 0001510fbf08dd4220ebf2\&docguid=I1b6583b0645d11e2bdc2010000000000\&hitguid=I1b6583b064 $5 \mathrm{~d} 11 \mathrm{e} 2 \mathrm{bdc} 2010000000000 \& \operatorname{spos}=2 \&$ epos $=2 \& \mathrm{td}=3 \&$ context $=18 \&$ startChunk $=1 \&$ endChunk $=1>$. Acesso em: 15 nov. 2015. 
CALAMANDREI, Piero. Direito Processual Civil. Estudos sobre o processo civil. Traduzido por Luiz Abezia e Sandra Drina Fernadez Barbery. v. 1. Campinas: Bookseller, 1999.

CARNELUTTI, Francesco. Sistema de Direito Processual Civil. Introdução e Função do Processo Civil. Traduzido por Hiltomar Martins Oliveira. v. I. São Paulo: Classic Book, 2000.

CASTILLO, Niceto Alcalá-Zamora Y. Estudios de Teoria General e História del Processo. Tomo 1, n. 1-11. México: Universidad Nacional Autónoma, 1992.

Proceso, Autocomposición y Autodefensa (Contribuición al estudio de los fines del processo). 1. reimpressão. México: Universidad Automona de México, 2000.

DEMERCIAN, Pedro Henrique; MALULY, Jorge Assaf. Juizados Especiais Criminais comentários. Rio de Janeiro: Aide, 1996.

GOMES, Marcus Alan de Melo. Culpabilidade e Transação Penal nos Juizados Especiais Criminais. São Paulo: Juarez de Oliveira, 2003.

GRINOVER, Ada Pellegrini; GOMES FILHO, Antônio Magalhães; FERNANDES, Antonio Scarance; GOMES, Luiz Flávio. Juizados Especiais Criminais: comentários à Lei 9.099 de 26.09.1995. 2. ed. rev., atual. e ampl. São Paulo: Revista dos Tribunais, 1997.

GROSSI, Ana Claudia. Pode o acordo ser uma solução para os problemas da morosidade e sobrecarga da justiça? - subsídios para um debate, a partir da experiência alemã. Revista Brasileira de Ciências Criminais, São Paulo: Revista dos Tribunais, v. 114, p. 133-171, mai - jun, 2015. Disponível em: <http://www.revistadostribunais.com.br/maf/app/resultList/document?\&src=rl\&srguid=i0ad8181500 000150c94e1b5ebd94cdce\&docguid=I7ff8c9a00e7d11e58211010000000000\&hitguid=I7ff8c9a00e7 $\mathrm{d} 11 \mathrm{e} 58211010000000000 \&$ spos $=1 \&$ epos $=1 \& \mathrm{td}=1$ \& context $=32 \&$ startChunk=1\&endChunk=1 >

Acesso em: 02 nov. 2015.

JARDIM, Afrânio Silva. Ação Penal Pública. 4. ed. rev. e atual. segundo a lei 9.099/95. Rio de Janeiro: Forense, 2001.

Direito Processual Penal. 6. ed. rev. e atual. Rio de Janeiro: Forense, 1997.

JARDIM, Afrânio Silva. Os Princípios da Obrigatoriedade e Indisponibilidade da Ação Penal Pública nos Juizados Especiais Criminais. Revista da Escola Superior do Ministério Público do Distrito Federal, Distrito Federal, ano 3, n. 6, p. 24, jun/dez. 1996. Disponível em: <http://www.buscalegis.ufsc.br/revistas/files/anexos/16954-16955-1-PB.htm>. Acesso em: 07 jun. 2014.

KARAM, Maria Lúcia. Anotações sobre aspectos penais e processuais penais das leis 9.099/95 e 10.259/2001 - leis dos juizados especiais. Doutrinas Essenciais Processo Penal. São Paulo: Revista dos Tribunais, v. 4, p. 1153, jun. 2012. Disponível em: <http://www.revistadostribunais.com.br/maf/app/resultList/document?\&src=rl\&srguid=i0ad6007a00 $00014 \mathrm{~d} 4 \mathrm{ea} 8 \mathrm{~d} 88933 \mathrm{~d} 31 \mathrm{fda} \& d$ docguid=Ic4888bc0f25111dfab6f010000000000\&hitguid=Ic4888bc0f25 $111 \mathrm{dfab} 6 \mathrm{f} 01000000000 \&$ spos $=3 \&$ epos $=3 \& \mathrm{td}=11 \&$ context $=74 \&$ startChunk $=1 \&$ endChunk $=1>$. Acesso em: 13 mai. 2015. 
MACHADO, Agapito. A sentença penal e o código penal brasileiro de 1984. Revista dos Tribunais, São Paulo: Revista dos Tribunais, v. 671, p. 271 - 284, set. 1991. Disponível em: <http://www.revistadostribunais.com.br/maf/app/resultList/document?\&src=rl\&srguid=i0ad8181500 0001510b797eab9e154f39\&docguid=I118f8c90f $25011 \mathrm{dfab} 6 f 010000000000 \&$ hitguid=I118f8c90f 25 011dfab6f010000000000\&spos=2\&epos=2\&td=18\&context=98\&startChunk=1\&endChunk=1>.

Acesso em: 14 nov. 2015.

MIRABETE, Julio Fabbrini. Juizados Especiais Criminais - comentários, jurisprudência, legislação. 4. ed. rev. e atual. São Paulo: Atlas, 2000.

MIRANDA, Pontes de. Tratado de direito privado. v. III, Rio de Janeiro: Borsói, 1954.

MOLINA, Antonio García-Pablos de; GOMES, Luiz Flávio. Criminologia. 8. ed. rev., atual. e ampl. Coleção Ciências Criminais. v. 5. São Paulo: Revista dos Tribunais, 2012.

MOREIRA, José Carlos Barbosa. Conteúdo e efeitos da sentença: variações sobre o tema. Revista de Processo, São Paulo: Revista dos Tribunais, v. 40, [sp], out. 1985. Disponível em: <http://www.revistadostribunais.com.br/maf/app/latestupdates/document?\&src=rl\&srguid=i0ad8181 $5000001510 \mathrm{~b} 6 \mathrm{fccf} 85 \mathrm{a} 32 \mathrm{f} 966 \&$ docguid $=\mathrm{I} 2 \mathrm{aa} 558 \mathrm{c} 0 \mathrm{f} 25711 \mathrm{dfab} 6 \mathrm{f} 010000000000 \&$ hitguid=I2aa558c0f

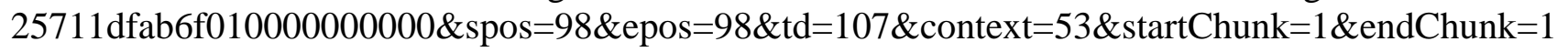
>. Acesso em: 14 nov. 2015.

. La transaccion penal brasileña y el derecho norteamericano. Revista de Processo, São Paulo: Revista dos Tribunais, v. 100, p. 131, out. 2000. Disponível em: <http://www.revistadostribunais.com.br/maf/app/latestupdates/document?\&src=rl\&srguid=i0ad6007 a0000014d549889201872ee77\&docguid=I81f0dec0f25611 dfab6f010000000000\&hitguid=I81f0dec0 f25611 dfab6f010000000000\&spos $=65 \&$ epos $=65 \& \mathrm{td}=107 \&$ context $=29 \&$ startChunk $=1 \&$ endChunk $=$ 1>. Acesso em: 13 mai. 2015.

NUCCI, Guilherme de Souza. Código Penal Comentado. 14. ed., ver, atual. e ampl. Rio de Janeiro: Grupo Gen, 2014.

PANZERI, André de Almeida. A sanção de perda de bens no direito penal econômico - análise comparativa dos modelos português e brasileiro. Doutrinas Essenciais de Direito Penal Econômico e da Empresa. São Paulo: Revista dos Tribunais, v. 2, p. 43-79, jul. 2011. Disponível em:<http://www.revistadostribunais.com.br/maf/app/resultList/document?\&src=rl\&srguid=i0ad8181 5000001510b69c0aeeb4712a1\&docguid=Ie56e83502d5511e0baf30000855dd350\&hitguid=Ie56e835 02d5511e0baf30000855dd350\&spos $=1 \&$ epos $=1 \& \mathrm{td}=1 \&$ context $=6 \&$ startChunk $=1 \&$ endChunk $=1 .>$ Acesso em: 14 nov. 2105.

PINHO, Humberto Dalla Bernardina de. A Introdução do instituto da Transação Penal no direito brasileiro - e as questões daí decorrentes. Rio de Janeiro: Lúmen Juris, 1998.

PORTO, Hermínio Alberto Marques; NERY JUNIOR, Nelson. Juizados especiais para julgamento das infrações penais de menor potencial ofensivo. Doutrinas Essenciais Processo Penal. São Paulo: Revista dos tribunais, vol. 4, p. 867 - 887, jun. 2012. Disponível em: <http://www.revistadostribunais.com.br/maf/app/resultList/document?\&src=rl\&srguid=i0ad6007a00 0001511006feaa18e4d0b4\&docguid=I41681160f $25711 \mathrm{dfab} 6 f 010000000000 \&$ hitguid=I41681160f 2 5711 dfab6f010000000000\&spos=1\&epos=1\&td=1\&context=34\&startChunk=1\&endChunk=1>. Acesso em: 03 nov. 2015. 
PRADO, Geraldo Luiz Mascarenhas. Elementos para uma análise crítica da Transação Penal. Rio de Janeiro: Lúmen Juris, 2003.

REALE JÚNIOR, Miguel. Simplificação processual e desprezo ao direito penal. Doutrinas Essenciais Processo Penal. São Paulo: Revista dos tribunais, vol. 1, p. 321 - 345, jun. 2012. Disponível em:

<http://www.revistadostribunais.com.br/maf/app/resultList/document?\&src=rl\&srguid=i0ad8181600 0001510b7fafe082b876d4\&docguid=I85a169b0d45d11e0ba7b00008558bdfc\&hitguid=I85a169b0d4 $5 \mathrm{~d} 11 \mathrm{e} 0 \mathrm{ba7b} 00008558 \mathrm{bdfc} \& \operatorname{spos}=2 \&$ epos $=2 \& \mathrm{td}=29 \&$ context $=131 \&$ startChunk=1\&endChunk=1 . Acesso em: 14 nov. 2015.

SANTORO FILHO, Antônio Carlos. A natureza jurídica da Transação Penal. Tribuna da Magistratura: Caderno de Doutrina, São Paulo: Aasp, p. 9-11, mai. 1996.

SANTOS, Lycurgo de Castro. A natureza jurídico-penal da multa e da restrição de direitos na Transação Penal (Lei 9.099/95). Boletim IBCCRIM, ano 4, n. 38, [sp], fev. 1996. Disponível em: <http://www.ibccrim.org.br/boletim/58-38-Fevereiro-1996/?ano_filtro=1996>. Acesso em: 13 mai. 2015.

Culpabilidade e pena na lei 9.099/95. Revista Brasileira de Ciências Criminais, São Paulo: Revista dos Tribunais, v. 13, p. 130, jan. 1996. Disponível em: <http://www.revistadostribunais.com.br/maf/app/resultList/document?\&src=rl\&srguid=i0ad6007900 00014d4ea44abffbe3d606\&docguid=I8c94a9b0f25111dfab6f010000000000\&hitguid=I8c94a9b0f 25 $111 \mathrm{dfab6f010000000000 \& spos}=5 \&$ epos $=5 \& \mathrm{td}=6 \&$ context $=41 \&$ startChunk $=1 \&$ endChunk=1 $>$. Acesso em: 13 mai. 2015.

SILVA, Ovídio Araujo Baptista da. Conteúdo da sentença e coisa julgada. Doutrinas Essenciais de Processo Civil. São Paulo: Revista dos Tribunais, v. 6, p. 287, out. 2011. Disponível em: <http://www.revistadostribunais.com.br/maf/app/resultList/document?\&src=rl\&srguid=i0ad8181500 0001510b76984687ecac94\&docguid=I0965fe80f25711dfab6f010000000000\&hitguid=I0965fe80f 25

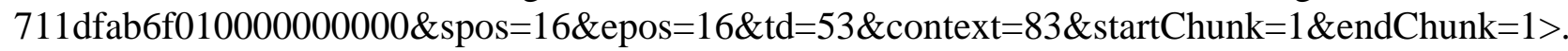
Acesso em: 14 nov. 2015.

SIRVINSKAS, Luís Paulo. A autonomia privada, a Transação Penal e seus efeitos civis. Revista dos Tribunais, São Paulo: Revista dos Tribunais, v. 780, p. 460, out. 2000. Disponível em: <http://www.revistadostribunais.com.br/maf/app/resultList/document?\&src=rl\&srguid=i0ad6007a00 00014d4eda7fcd9e5daca8\&docguid=Id0186790f $25011 \mathrm{dfab} 6 f 010000000000 \&$ hitguid=Id0186790f 25 $011 \mathrm{dfab} 6 \mathrm{f} 010000000000 \&$ spos $=8 \&$ epos $=8 \& \mathrm{td}=9 \&$ context $=6 \&$ startChunk=1\&endChunk=1>. Acesso em: 13 mai. 2015.

TOURINHO FILHO, Fernando da Costa. Comentários à Lei dos Juizados Especiais Criminais. São Paulo: Saraiva, 2000.

TOURINHO NETO, Fernando da Costa; FIGUEIRA JÚNIOR, Joel Dias. Juizados Especiais Estaduais Cíveis e Criminais. Comentários à Lei 9.099/1995. 7. ed. rev., atual. e ampl. São Paulo: Revista dos Tribunais, 2011.

TUCCI, Rogério Lauria. Sentença Penal. Doutrinas Essenciais Processo Penal. São Paulo: Revista dos Tribunais, v. 5, p. 263, jun. 2012. Disponível em: 
<http://www.revistadostribunais.com.br/maf/app/resultList/document?\&src=rl\&srguid=i0ad8181500 0001510b76984687ecac94\&docguid=I0965fe80f25711dfab6f010000000000\&hitguid=I0965fe80f 25

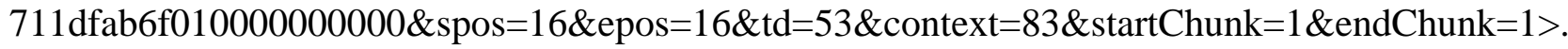
Acesso em: 14 nov. 2015.

WAMBIER, Luiz Rodrigues. Execução de sentença que homologa transação que trata de obrigação de fazer ou não fazer. Peculiaridades. Necessidade de relação processual autônoma. Presença de mero juízo de delibação. Necessidade de citação da parte transigente tida por inadimplente. Oportunidade de exercício do direito de defesa. Prazo para os embargos. Revista de Processo, São Paulo: Revista dos Tribunais, v. 114, p. 240, mar. 2004. Disponível em: <http://www.revistadostribunais.com.br/maf/app/latestupdates/document?\&src=rl\&srguid=i0ad8181 500000150c9504a6ede8f7a47\&docguid=I98033320f 25611 dfab6f010000000000\&hitguid=I9803332 0f $25611 \mathrm{dfab} 6 \mathrm{f} 010000000000 \&$ spos $=63 \&$ epos $=63 \& \mathrm{td}=87 \&$ context $=61 \&$ startChunk $=1 \&$ endChunk $=$ 1.>. Acesso em: 02 nov. 2015.

ZANATTA, Airton. A Transação Penal e o poder discricionário do ministério público. Porto Alegre: Sergio Antonio Fabris, 2001.

Recebido em: 03/03/2016

Aceito em: 22/08/2016 
O Recurso Extraordinário n. 795.567/PR, análise dos fundamentos do acórdão em face da natureza jurídica da Transação Penal.

Revista da Faculdade de Direito da UFRGS, Porto Alegre, n. 35, p. 287-307, dez. 2016.

ISSN: 0104-6594 Site http://seer.ufrgs.br/revfacdir

Faculdade de Direito da UFRGS - Rua Riachuelo, 1317 - Centro - Porto Alegre - RS - Brasil 